dummy from another. Willow-warblers will attack a stuffed cuckoo but will not go near a stuffed sparrowhawk. Nightingales will attack both hawk and cuckoo, but fear a stuffed stoat. Blackbirds disregard a cuckoo but attack a jay. Tree-pipits attack a cuckoo violently, but will not approach a jay; whin. chats attack both cuckoo and sparrow-hawk. The article contains a detailed account of these reactions as well as many excellent close-up photographs which were taken during the experiments.

26

Mushroom Diseases

A SMALI booklet has recently been compiled by Mr. Fred C. Atkins Jntitled "Major Diseases of the Cultivated Whit Y shroom" (Yaxley, Peterborough : Midlands ynodp Publications, 1948; 2s. 6d.). It deals with bfcterial pit, caused by Pseudomonas (?) fletprescens, bacterial blotch (Phytomonas Tolaasi), cobveb or mildew due to Dactylium dendroides, bubble (Mycogone perniciosa) and brown spot (Verticillium spp.). Most of the descriptions have appeared in the Bulletin of the Mushroom Growers' Association; but practical growers and others will welcome their collection into a booklet with photographs, drawings and succinct accounts of control. It is planned to issue further booklets on major competitors, and on minor diseases and competitors of the cultivated mushrpom.

\section{Unstability in the Rust Fungi}

THe life-history ofy rust fungus is usually regarded as sufficiently solle to have some diagnostic value. Recent nowlefge shows, however, that there are exceptio . Mid colm Wilson (Proc. Roy. Soc. Edin., B, 63, P tt 2, No. 11, 177; 1948) reviews the literture 8 aling with instability, and describes four British cases where uredosori contained a proportion of teleutospores. All the unstable species now known belong to the Pucciniaceæ, a relatively advanced family of the rust fungi. The taxonomic position of their host species also agrees with their relatively advanced condition. The interesting theory that unstable species lead to the production of microPuccinia forms is now formulated, and seems to provide a useful insight into the phylogeny of these organisms. Special environmental conditions appear to induce instability of life-history, and this itself is another interesting feature.

\section{Strains of Host and Virus}

StraIns of various virus diseases are now well recognized by reafa ch workers. B. Kassanis and Ireson W. Nalin (\%. Pomol. Hort. Sci., 23, Nos. 3, 4; Del 19:7) now demonstrate two strains in a ho plant (Uthite Burley tobacco), which are barely dist iguishable morphologically, but react differently to virus infection. Tomato aucuba mosaic produces necrotic local lesions or systemic necrosis in one host strain, and a yellow mottle in the other. Some strains of tobacco mosaic also react necrotically in the firstmentioned host strain. This unsuspected selective action of the host may possibly explain discrepancies in etiology reported by various workers. The behaviour of various strains of potato virus $Y$ has also been studied by F. C. Bawden and B. Kassanis (Ann. Appl. Biol., 34, No. 4, 503-516; Dec. 1947). These various strains cause diseases in the variety Majestic, ranging in severity from mild mosaic to leaf-drop streak. Symptoms of the strains are also compared with the serologically related potato virus
$C$, and possible mechanisms for the evolution of viruses $C$ and $Y$ are discussed.

\section{Science and Society

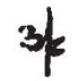

THE Education Ceptres Association is arranging a non-technical co Ase for laymen and men of science who want dopportunity of studying the relations betweemscience and society ; it is to be held at West. harr Halse, Barford, near Leamington, Warwickshire, daring August 20-27. Inquiry will be made into the application of science to the raising of the standard of living and of bodily health; and in considering the reciprocal issues between science and society particular attention will be paid to recent developments in industrial and agricultural practice and to such topical questions as the atomic bomb and the Lysenko controversy. The course will be conducted by lectures and by seminar discussions, and during the latter students will concentrate either on chemical and physical considerations or on biology as applied to nutrition and disease. Further particulars can be obtained from the Education Secretary, Educational Centres Association, 8 Endsleigh Gardens, London, W.C.1.

\section{Announcements}

A CONFERANCE on "The Place of Agriculture in Education will be held at Lord Wandsworth College, Long Satton, near Basingstoke, Hants, on July 20. Thy conference will be opened by the Minister of Agriculture. Further information may be obtained from the bursar of the College, Mir. L. G. Troup.

THE fourteenth Cold Spring Harbor Symposium on Quantitative Biolog will be held during June 8-16. The topic is "Mmino Acids and Proteins", with emphasis on hological aspects of the problem. The meeting wil be international in scope, those taking part coning from Denmark ( $\mathrm{K}$. Linderstrøm-Lang), Frane (C. Fromageot), Great Britain (D. Crowfoot, J. T. Danielli, F. Sanger and R. L. M. Synge), and Sweden (K. O. Pedersen). Attendance is restricted, on account of limitations of space, to about a hundred. The programme and other information can be obtained from the Biological Laboratory, Cold Spring Harbor, New York.

THE Chemical Research Laboratory (Department of Scientificand Industrial Research), at Teddington, Viiddlesel, is again holding a series of 'open days' this yar. There will be three sessions, on June 30 (afternoon), and on July 1 (morning and afternoon). Applications from industrial firms wishing to send representatives should be sent to the Director before June 20; those already on the invitation list need not apply again.

Prof. C K. Ingowd points out that extended series gf Fermi doublets of the kind that Prof. R. K. Asuydi and M. E. Padhye report (Nature, April 23, p 638) in the near ultra-violet emission spectrum of benzene, as well as analogous series in the absorption spectrum, have been fully described and discussed by Dr. F. M. Garforth and himself (J. Chem. Soc., 417, 427 ; 1948).

REFERENCE was made in the leading article of Nature of May 7 to a recently published book "The Unity of European History" (London: Jonathan Cqpo, Ltd., 18s. net), by Mr. John Bowle. We regret that, throughout the article, the author's name was spelled incorrectly. 